\title{
The ways of Improving the Innovation Management in Ukraine Using the International Development
}

\author{
Prof., DrS Viktoriia Bokovets ${ }^{1}$, Assoc. Prof., PhD Olena Moskvichova ${ }^{2}$, \\ Assoc. Prof., PhD Iryna Hryhoruk ${ }^{3}$, Assoc. Prof., PhD Svetlana Suprunenko ${ }^{4}$
}

\begin{abstract}
In the world economic space there is a complex transition from industrial technological system to postindustrial, in which the high tech, informatization and knowledge economy takes on the dominating role of the driving forces of development. Naturally, for such a turn of events, economic science was not well prepared, and today there is a certain gap between the practice of accelerated changes and the scientific provision of these processes. First of all, it concerns the development of a strategy and mechanisms for the development of the country's economy and identifying opportunities for realizing its innovative potential by doing innovative management. The researchers consider innovative management in their work in a number of aspects: science and art of innovative management (I. Dichkivska, P. Zavlin); kind of administrative activity in making decisions on innovations (I. Balabanov, M. Yon, V. Stadnik,); management of innovations (N. Kruglov, A. Porshnev); a system of rules of principles, norms, values orientations that regulate various spheres of innovation activity (V. Vasilenko, L. Oholova). In innovative management, the methods of sociopsychological series, heuristic and collegial (I. Ansoff, B. Gates, L. Karuushkha, A. Morita) prevail. There is a change in the general functions, structure and objectives of management (L. Danilenko, L. Oholova), there are special means and forms of organization of innovation activity (V. Vasilenko, L. Vashchenko).The study of literary sources and their generalization shows the importance of this issue, and requires a more in-depth study and analysis of international experience in implementing innovative measures. The research objective. The main purpose of this study is to analyze measures to stimulate innovation development in the countries of the world, assessment of their effectiveness, as well as consideration of the directions on the basis of their activation of innovation activity in Ukraine. The article reveals the essence of the concept of "innovative management", analyzes the international experience in implementing and stimulating the innovation process. Thus, to summarize, it can be concluded that the experience of leading countries in stimulating innovation usually involves quite similar measures, namely: subsidies, tax cuts or, in some cases, tax holidays, payment of a share of $\mathrm{R} \& \mathrm{D}$ expenditure. The following organizations are created: informational, technical, financial support for business engaged in innovation activities. Stimulates the development of innovations at the level of universities and other scientific institutions.
\end{abstract}

Keywords: innovative management; innovative activity; innovative measures; R\&D; innovation.

\section{Introduction}

In the world economic space there is a complex transition from industrial technological system to postindustrial, in which the high tech, informatization and knowledge economy takes on the dominating role of the driving forces of development. Naturally, for such a turn of events, economic science was not well prepared, and today there is a certain gap between the practice of accelerated changes and the scientific 
provision of these processes. First of all, it concerns the development of a strategy and mechanisms for the development of the country's economy and identifying opportunities for realizing its innovative potential by doing innovative management.

The researchers consider innovative management in their work in a number of aspects: science and art of innovative management (I. Dichkivska, P. Zavlin); kind of administrative activity in making decisions on innovations (I. Balabanov, M. Yon, V. Stadnik,); management of innovations (N. Kruglov, A. Porshnev); a system of rules of principles, norms, values orientations that regulate various spheres of innovation activity (V. Vasilenko, L. Oholova). In innovative management, the methods of sociopsychological series, heuristic and collegial (I. Ansoff, B. Gates, L. Karuushkha, A. Morita) prevail. There is a change in the general functions, structure and objectives of management (L. Danilenko, L. Oholova), there are special means and forms of organization of innovation activity (V. Vasilenko, L. Vashchenko). An important place in innovative management belongs to the project activity (A. Porshnev, N. Solomatin, V. Ustinov).

\section{Area under study}

Identification of unexamined aspects of the general problem. The study of literary sources and their generalization shows the importance of this issue, and requires a more in-depth study and analysis of international experience in implementing innovative measures.

Problem definition. The main purpose of this study is to analyze measures to stimulate innovation development in the countries of the world, assessment of their effectiveness, as well as consideration of the directions on the basis of their activation of innovation activity in Ukraine.

\section{Results}

Every year of the XXI century, the process of synchronizing economic development with the achievements of science and the trends of introducing new technologies into any human activity sphere is intensified. The sluggishness or lack of efficiency of the structural adjustment of any entity of the global economic system in accordance with the requirements of the new technological structure turns not only into the loss of development prospects, but also leads to complete economic degradation and innovation rate making this process fairly operational. In such circumstances, it is important to effectively and timely implement innovations in all sectors of the country's economy and manage them; for this reason, there was a "innovative management".

Innovation management is a general management subsystem whose purpose is to manage innovative processes in the organization. "In order to optimize its economic activity economic results" [1], "Innovative management as a system - a set of economic, motivational, organizational and legal means, methods and forms of management of innovative activities of the organization".

The main functions, tasks of innovation management are as follows: analytical and forecasting, planning, organization, control, regulation.

Analytical and prognostic activity of the manager is connected with a deep 
analysis of the state of the system, the study of urgent problems, tracing trends and patterns, identifying perspectives and projected changes in the future; provides for the development of forecasts for the feasibility of upgrades and methods for upgrading the systems, filling up with new content activities.

The function of planning in innovative management involves the development of strategic and tactical plans for the introduction of innovations.

The function of the organization is to ensure that people's activities are streamlined during the introduction of innovation, division of powers and responsibilities for individual parts of the work. The following activities, such as coordination and promotion, are becoming dominant. Coordination in innovative management helps to avoid excessive chaos, arrhythmias during the development of the organization. The stimulus provides a high level of employee interest in innovation work and its outcomes.

Among the most knowledge-intensive industries, experts from the Organization for Economic Cooperation and Development (OECD), based on a number of generally recognized capacity criteria $(\mathrm{R} \& \mathrm{D}$ costs in relation to added value or volume of industry supplies, etc.) are:

- aerospace branch;

- production of office and computer equipment;

- production of communication facilities;

- Pharmaceutical and medical industry.

According to OECD experts, the most promising instruments of state policy in the long-term perspective, in addition to traditional measures to improve the quality of labor resources and increase investment, advocate actions to attract information and telecommunication technologies, innovations and entrepreneurial activity to the process of economic growth. To succeed in this context, countries must first of all ensure a number of prerequisites for increasing domestic R\&D expenditures (table 1), since R\&D (creation of new high-quality products based on the latest technologies) plays a leading role in providing innovative responses in post-industrial development (the desire to optimize the parameters and timing of the development of new products, as well as marketing strategies within the strategic zones of enterprise management in order to increase the long-term sweat profitability and guaranteeing competitiveness in traditional and emerging markets).

Table 1: Domestic R\&D expenditures in G7 countries

\begin{tabular}{|l|c|c|c|}
\hline Country & $\begin{array}{c}\text { Total billion dollars } \\
\text { USA }\end{array}$ & $\begin{array}{c}\text { Share of } \\
\text { GDP, } \%\end{array}$ & Per person, dollars USA \\
\hline USA & 252,2 & 2,7 & 901,2 \\
\hline Canada & 13,8 & 1,7 & 450,5 \\
\hline Japan & 94,7 & 3,2 & 761,5 \\
\hline France & 28,5 & 2,1 & 865,7 \\
\hline Great Britain & 28,2 & 1,9 & 431,2 \\
\hline Germany & 48,3 & 2,4 & 608,1 \\
\hline Italy & 14,1 & 1,2 & 248,3 \\
\hline
\end{tabular}

Sources: grouped by authors [2]. 
The control function allows you to check the progress of the implementation of innovation, the effectiveness of the innovative approach to activities. The main means of innovation control are monitoring, expertise, information analysis.

Regulation in innovation management involves the correction of the activity of introducing innovations by the control effects, creating a situation of relative stability and equilibrium, preventing deviations from the planned innovation standards.

Today it is important to invest in research and development $(\mathrm{R} \& \mathrm{D})$, that is, the development of the latest technologies for the transition to post-industrial system.

As a result, the United States (United States) continues to occupy the leading position in creating and moving to the market of goods and services based on technologies of the Fifth Form, the second place falls on Japan. The countries of Western Europe, seeking to maintain their positions and even outpacing competitors in a number of areas, widely use the benefits of international economic integration and scientific and technical cooperation. Let's consider the experience of some countries in more detail. Thus, in the United States, the state, which supports research organizations, venture business and enterprises, which initiates and implements innovative changes in the implementation of the innovation strategy, will play an important role in the development of innovation activity (table 2).

Table 2: Tools for stimulating innovation in the United States

\begin{tabular}{|c|c|}
\hline $\begin{array}{l}\text { Subjects of } \\
\text { the innovation } \\
\text { process }\end{array}$ & Types of stimulation \\
\hline $\begin{array}{l}\text { Research } \\
\text { organization }\end{array}$ & $\begin{array}{l}\text { 1. Exclusion of up to } 20 \% \text { of } \mathrm{R} \& \mathrm{D} \text { expenditures related to the } \\
\text { main activity from the amount of taxable income }\end{array}$ \\
\hline $\begin{array}{l}\text { Venture } \\
\text { business and other } \\
\text { sources of financing }\end{array}$ & $\begin{array}{l}\text { 1. There is no rental tax for venture companies. } \\
\text { 2. Reduction of income tax for organizations with securities of } \\
\text { venture structures ( } 60 \% \text { - not taxed, } 40 \% \text { - taxed by ordinary taxes). } \\
\text { 3. Guaranteed by the Small Business Administration (AMB) up to } \\
90 \% \text { return on investment in venture capital business. } \\
\text { 4. Provision of AMB subsidies to the venture business to } 100 \\
\text { thousand dollars. for } 8 \text { years - for expansion of foreign economic activity } \\
\text { and up to } 1 \text { million dollars. for } 25 \text { years - for various types of management } \\
\text { assistance. } 5 \text {. Mandatory allocation by the federal agencies of funds (not less } \\
\text { than 1,25\% of the budget of the department) to finance the venture } \\
\text { business from its budget. } \\
\text { 6. According to US law, in case of project value more than } 100 \\
\text { thousand dollars. obligatory engagement of venture companies to } \\
\text { implement large-scale innovation projects. } \\
\text { 7. Preferential taxation of up to } 20 \% \text { increase in R \& D } \\
\text { expenditures of venture companies compared to the average annual level of } \\
\text { these expenditures in previous years taxable income. }\end{array}$ \\
\hline
\end{tabular}




\begin{tabular}{|c|c|}
\hline $\begin{array}{l}\text { Subjects of } \\
\text { the innovation } \\
\text { process }\end{array}$ & Types of stimulation \\
\hline $\begin{array}{l}\text { Enterprise } \\
s \text { that initiate and } \\
\text { innovate }\end{array}$ & $\begin{array}{l}\text { 1. Preferential taxation of firms that carry out R\&D in the amount } \\
\text { of up to } 20 \% \text { increase in the cost of R\&D compared to the average annual } \\
\text { level of these expenditures in previous years. } \\
\text { 2. Preferential taxation of up to } 20 \% \text { of company costs for } \\
\text { fundamental research programs run by universities under contract with } \\
\text { enterprises. Tax deductible deductions for the cost of scientific equipment } \\
\text { and equipment, which is freely provided by companies to universities and } \\
\text { research organizations. } \\
\text { 3. Privileged mode of depreciation - the life of equipment up to } 3 \\
\text { years, and for other funds - up to } 5 \text { years. } \\
4 \text {. Provision of investment tax credit, namely reduction of income } \\
\text { tax in the amount of } 6 \% \text { to } 10 \% \text { of the total cost of investment in } \\
\text { equipment. }\end{array}$ \\
\hline
\end{tabular}

Sources: grouped by authors [3].

The innovation strategy in the United States is focused on building competitive advantages through the creation of fundamentally new products and technologies that have no analogues in the market or the satisfaction of needs in a new way, which should provide increased profitability and the ability to take a dominant market share. To implement the innovation strategy, significant research and development costs are needed.

In the UK, stimulation of innovation is carried out through the introduction of innovation activity support programs (Mercia, Connect, Enterprise Fellowshipscheme, Medici), the provision of a range of benefits and the creation of venture companies (Table 3).

Table 3: Tools for stimulating innovation in the UK

\begin{tabular}{|c|c|}
\hline $\begin{array}{l}\text { Subjects } \\
\text { of the innovation } \\
\text { process }\end{array}$ & Types of stimulation \\
\hline $\begin{array}{l}\text { Researc } \\
\text { h organization }\end{array}$ & $\begin{array}{l}\text { 1. Providing small enterprises with access to ministerial orders for } \\
\text { R\&D. Each participating ministry allocates } 2.5 \% \text { of its orders to small } \\
\text { businesses. }\end{array}$ \\
\hline $\begin{array}{l}\text { Venture } \\
\text { business and } \\
\text { other sources of } \\
\text { financing }\end{array}$ & $\begin{array}{l}\text { 1. Reducing to } 25 \% \text { of the income tax for venture companies (instead of } \\
35 \% \text { of the current rate). } \\
\text { 2. System of insurance of funds provided to venture companies by } \\
\text { the state (the return of } 70 \% \text { of long-term loans, granted for a period of } 2-7 \\
\text { years). }\end{array}$ \\
\hline
\end{tabular}




\begin{tabular}{|c|c|}
\hline $\begin{array}{c}\text { Subjects } \\
\text { of the innovation } \\
\text { process }\end{array}$ & \multicolumn{1}{c|}{ Types of stimulation } \\
\hline & $\begin{array}{c}\text { 1. Up to } 50 \% \text { of the cost of innovation under the state programs for } \\
\text { Enterpr }\end{array}$ \\
$\begin{array}{c}\text { ises that initiate } \\
\text { and innovate }\end{array}$ & $\begin{array}{l}\text { 3. Write-off at any cost of R\&D on the cost of production (services). } \\
\text { enterprises to demonstrate the results of R\&D and technology and the } \\
\text { development of innovation infrastructure. }\end{array}$ \\
\hline
\end{tabular}

Sources: grouped by authors [3]

It is also worth considering measures to stimulate innovation in Germany, because it has significant success, for this it implements the following actions (Table 4).

Table 4: Tools for stimulating innovation processes in Germany

\begin{tabular}{|c|c|}
\hline $\begin{array}{l}\text { Subjects of } \\
\text { the innovation } \\
\text { process }\end{array}$ & Types of stimulation \\
\hline $\begin{array}{l}\text { Research } \\
\text { organization }\end{array}$ & $\begin{array}{l}\text { 1. Discount on private investment in R\&D to } 7.5 \% \text { of taxes. } \\
\text { 2. Payment of expenses for the technical examination of the } \\
\text { projects, assessment of the possibilities of patenting the results of the R\&D } \\
\text { (up to } 8 \% \text { of the costs of engineering and other consultations). } \\
\text { 3. Granting grants for up to three years for the qualification of } \\
\text { research staff (no more than five employees from each firm), namely for } \\
\text { internships in scientific institutes, other public and private research } \\
\text { organizations. } \\
\text { 4. Grants for small enterprises to invest in R\&D and movable } \\
\text { property, as well as investment in real estate used for research and } \\
\text { development, in the amount of } 20 \% \text { of the value of acquired or created } \\
\text { property within its value to } 500 \text { thousand euros. }\end{array}$ \\
\hline $\begin{array}{l}\text { Enterprise } \\
\mathrm{s} \text { that initiate and } \\
\text { innovate }\end{array}$ & $\begin{array}{l}\text { 1. Provision of targeted non-subsidized subsidies to enterprises } \\
\text { that develop new technologies for no more than } 54 \text { thousand euros for the } \\
\text { purchase and installation of new technological equipment and up to } 900 \\
\text { thousand euros for the introduction of improvements for up to three years. } \\
\text { 2. Granting preferential loans to firms (up to } 50 \% \text { of the funds is } \\
\text { owned by the owner), annual sales of no more than } 300 \text { thousand euros, } \\
\text { investing in modernization of the enterprise, development of new products, } \\
\text { measures for the rational use of energy. } \\
\text { 3. Provision of up to } 100 \text { thousand euros of preferential loans to } \\
\text { small and medium enterprises, entering into industrial cooperation with } \\
\text { other firms. } \\
\text { 4. Grant subsidies up to } 7.5 \% \text { of the value of the purchased } \\
\text { property to small and medium-sized firms for the purchase of property for } \\
\text { the purpose of energy conservation. } \\
\text { 5. Subsidies to small and medium-sized firms for research or } \\
\text { development of new technology for the production of products in the }\end{array}$ \\
\hline
\end{tabular}




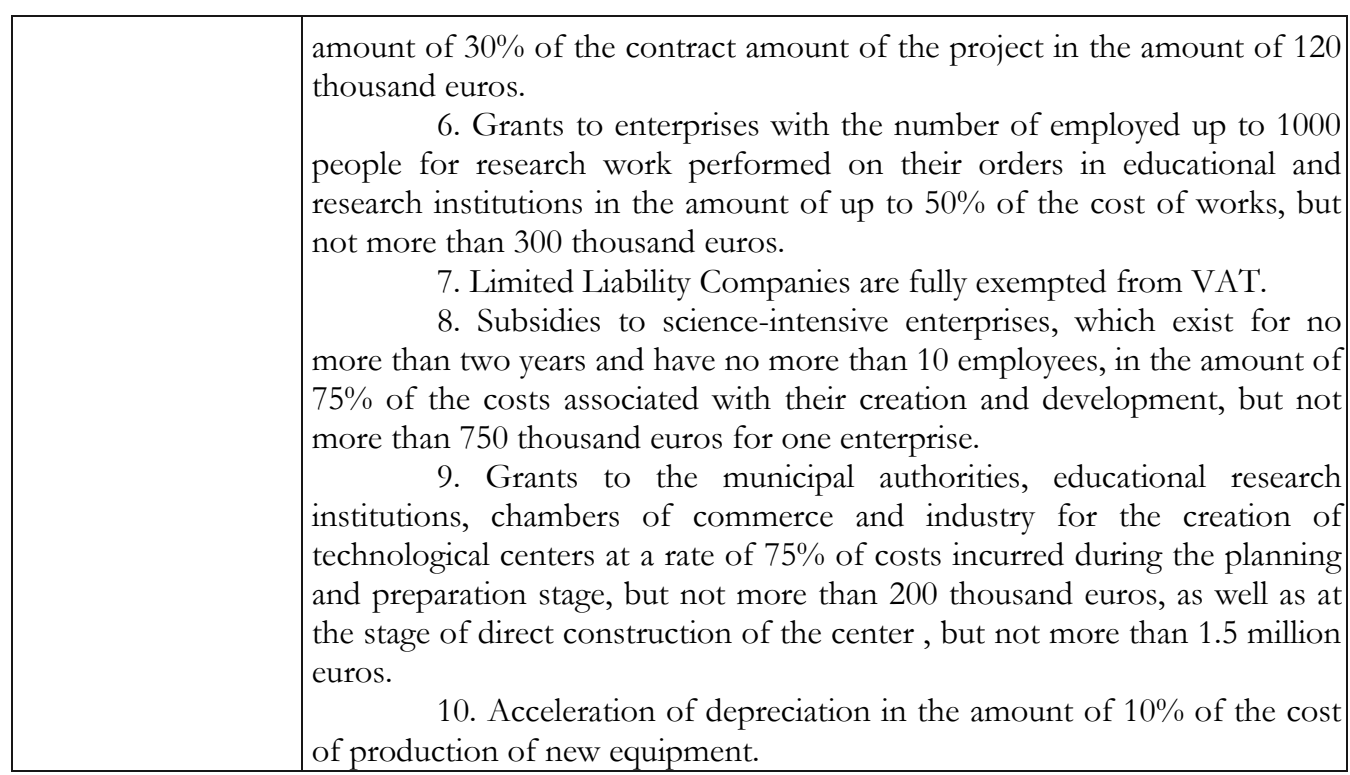

Sources: grouped by authors [3].

The main feature of the innovation activity of German companies is their ability to cooperate, whose content manifests itself first, in close collaboration with suppliers, higher education institutions and research institutes, and secondly, in the widely developed practice of creating production clusters. In addition, one of the key features of Germany's innovation policy is to provide the government with financial support for the development of long-term and risk studies in key areas of scientific, technical, and industrial activities. A special role in the field of innovation support lies with the HighTech Strategy, which was put into operation in 2006 and covers 17 "future areas" and aims to implement new technologies as soon as possible. In 2008, in addition to it, the Internationalization Strategy was adopted in order to attract researchers, students and foreign investments (with focus on R\&D). Germany also funds research projects to support research at universities.

\section{Conclusions}

So, summing up, it can be concluded that the experience of leading countries in stimulating innovation usually involves quite similar activities, namely: providing subsidies and subsidies, reducing taxes or, in certain cases, providing tax holidays, paying for a portion of $\mathrm{R} \& \mathrm{D}$ expenditures. The following organizations are created: information, technical, financial support of business which is engaged in innovative activity. Stimulates the development of innovations at the level of universities and other scientific institutions. 


\section{References}

1. Zamkova, N.L., Bokovets, V.V. (2017). Upravlinya innovatsiyami [Innovation Management]: Teach. Manual. Vinnitsa: Center. preparations sciences and teaching method. kind. VTEI KNUTE.

2. Goncharenko, L.P. (2013). Menedgment investiciy $i$ innovaciy [Investment and Innovation Management]. Moskva: KNORUS.

3. Petrova, I.L., Shpileva, T.I., Sysolina, N.P.; for sciences Ed. prof. I.L. Peter's (2010). Innovaciyna dijalnist' stimulu ta pereshkodu [Innovative activity: incentives and obstacles]: monograph. Kyiv: Dorado.

4. Prutskaya, T.Y., Bokovets, V.V. (2017). Formuvanya ta obgruntuvanya strategiyi innovatsiynogo rozvutky korporatuvnux pidpruyumstv [Formation and justification of the strategy of innovative development of corporate enterprises]. Market infrastructure, №6, p.79-85.

5. Kovtunenko, K.V. (2013). Innovation process and innovation activity as a driving force for the formation of the intellectual capital of an industrial enterprise. Economy. Management. Innovations, No. 1.

6. Sobko, O.Y. (2018). Foreign experience of reengineering of innovative activity of the enterprise. Materials of the IX All-Ukrainian Scientific and Practical Conference with International Participation "Modern Approaches to Enterprise Management. Kyiv, April 12, 2018. Kyiv: KPI them. Igor Sikorsky, p.34.

7. Nagornyak, G., Nagornyak, I., Vovk, Yu. (2013). Impact of technology transfer on innovation processes: Ukrainian and foreign experience. Socio-economic problems and the state, №2, p.117-127.

8. Sobko, O.Yu., Zhigalkevich, Zh.M. (2018). Features of foreign experience of reengineering of innovative activity of the enterprise. Materials of the IX All-Ukrainian Scientific and Practical Conference with International Participation "Modern Approaches to Enterprise Management. Kyiv, April 12, 2018. Kyiv: KPI them. Igor Sikorsky.

10. Morozova, S.A. (2018). Innovative activity of small and medium enterprises in the EU: experience for Ukraine. Economical space, №133. p.27-39. 